\title{
Policies on intergroup relations in Central and East European cities: a comparative analysis of Budapest, Prague, Wrocław and Tallinn
}

\begin{abstract}
This article explores the differences in the understanding of 'intergroup relations' and measures underaken in the area of intercultural policies in four Central and East European (CEE) cities: Budapest, Prague, Wrocław and Tallinn.

The analysis is based on interviews and field research carried out in 2008 in these cities in cooperation with local scientific experts, representatives of the ethnic communities and officials of the Municipalities as part of the Eurofound research project CLIP ${ }^{1}$. It explores the national and local political frameworks for intergroup policy and the target groups for such strategies and policies.

The main aim of this article is to carry out a comparative analysis of four cities from the CEE countries in order to indicate the similarities and differences in the understanding of intergroup relations. It investigates the type of actors involved in this process and whether their actions are catalysed from the top-down or bottom-up.
\end{abstract}

Keywords

CEE countries $\bullet$ intergroup policies $\bullet$ local policy-making $\bullet$ migration

(C) University of Warsaw - Faculty of Geography and Regional Studies

\section{Introduction}

In CEE countries, institutional and policy developments in the field of migration were shaped by the expansion of the European Union as well as by the dynamics of migration and refugee flows. This article analyses the development of strategies for intercultural policies in Budapest, Prague, Wrocław and Tallinn with the intention of answering the following questions:

- Which measures of intercultural policy in the four cities were already implemented and which are at the planning stage?

- To which extent are municipal policies in Central and Eastern Europe determined by the political and legal frameworks at the national level?

- Are there significant differences in municipal policies on intergroup relations between the four cities studied?

The analysis is based on data collected during field trips in 2008. The main aim of this paper is a systematic comparison of intercultural policies in cities where immigration is still a politically unfamiliar phenomenon.
Josef Kohlbacher

Patrycja Matusz Protasiewicz ${ }^{2}$

${ }^{1}$ Institut für Stadt- und Regionalforschung Zentrum Sozialwissenschaften, Österreichische Akademie der Wissenschaften e-mail: josef.kohlbacher@oeaw.ac.at

${ }^{2}$ Institute of International Studies University of Wroclaw e-mail: patrycja.matusz@gmail.com

Received: 18 July 2012

Accepted: 8 October 2012

${ }^{1}$ The CLIP (Cities for Local Integration Policies) research project was financed by Eurofound (European Foundation for the Improvement of Living and Working Conditions in Dublin) and coordinated by EFMS University of Bamberg. More information about project, methodology and tolls used by field work are available at http://www.eurofound.europa. eu/areas/populationandsociety/clip.htm. [20 April 2012].

\section{Theoretical considerations}

Policies on intercultural relations are one of the four domains of local migration policy (Alexander 2007: $48 \mathrm{ff}$ ). The migration policy arenas (Caponio 2010) take shape in specific national and historical contexts and different systems of state-municipality relations. In CLIP, intergroup relations were understood as interactions between different groups sharing the same urban space. In Western European cities, the immigrant population is very diverse and policy is often targeted at groups of immigrants. In CEE countries, the immigrant population has not yet been seen as the target group for a policy although national minorities do exist. After the transformation, national and local authorities were confronted with the need to develop group relations between different national minorities so we decided to broaden the definition of a 'group' to include national groups as well. It must be added that the national context is sometimes the only factor influencing the intergroup relations policy, which is why we often refer to it. 
The national context - data and policies

General migration policy related trends in the four CEE countries

Before 1989, in the Soviet Bloc countries the international movement of people was based on the very restrictive 'visa system'. In case of Hungary, shifting borders meant that a significant Hungarian diaspora remained in neighbouring countries while in Estonia, the post-war period saw the beginning of Russification and inflows of Russians to the country. Fig. 1 shows the similarities and differences in migration processes in Tallinn, Wrocław, Prague and Budapest.

The situation changed considerably after the fall of the Iron Curtain. Transformation became the starting point of an inflow of immigrants and circular and short-term labour migration is still the dominant form of migration. In Central and Eastern Europe, integration policy was characterised by four steps (Drbohlav 2009):

1. The early 1990s saw large immigration inflows and the domination of 'migration non-policies'.

2. In the mid-1990s, a legal framework for immigration was created.

3. From the late 1990 s to 2004 , policies were harmonised with EU standards.

4. Since 2004 there has been an observable consolidation of the migration regime.

In general, policy-making in the field of intergroup relations in CEE metropolises is still far from being as developed as in Western Europe, and local policies are informed and influenced by national frameworks. However, despite differences in national policy-making in Hungary (Hárs et al. 2009), the Czech Republic (Drbohlav 2009), Poland (Desponds, Lesińska 2008) and Estonia (Reinvelt 2000; Tesser 2005), similarities between mechanisms of local urban immigration policy can be observed.

National contexts: immigration and integration policies and policy-making structures

General characterisation

Although the CEE countries are in the early stages of the 'migration cycle', they differ in certain aspects. For example, the Czech Republic has entered the take-off stage of the migration cycle whereas Hungary seems to be at a preliminary stage (Drbohlav 2009). In both countries significant numbers of migrants settle there permanently whereas in Poland, short stays dominate. The integration of migrants seems to be in the infancy stage in all Central and East European urban contexts and there is some evidence of 'parallel society' building among the Chinese in Budapest (Nyíri 2007) and the Vietnamese in Prague (Brouček 2003). In Estonia there is a visible division between Estonians and Russian-speakers in all spheres of social life (Matusz Protasiewicz 2009a).

Hungary

According to OECD data, in 2008 the immigrant population numbered about 316,000 inand the net migration rate was very low at 0.86 migrants per 1,000 inhabitants. Hungary's migration policy is not decided by a specific political actor or ministry, but

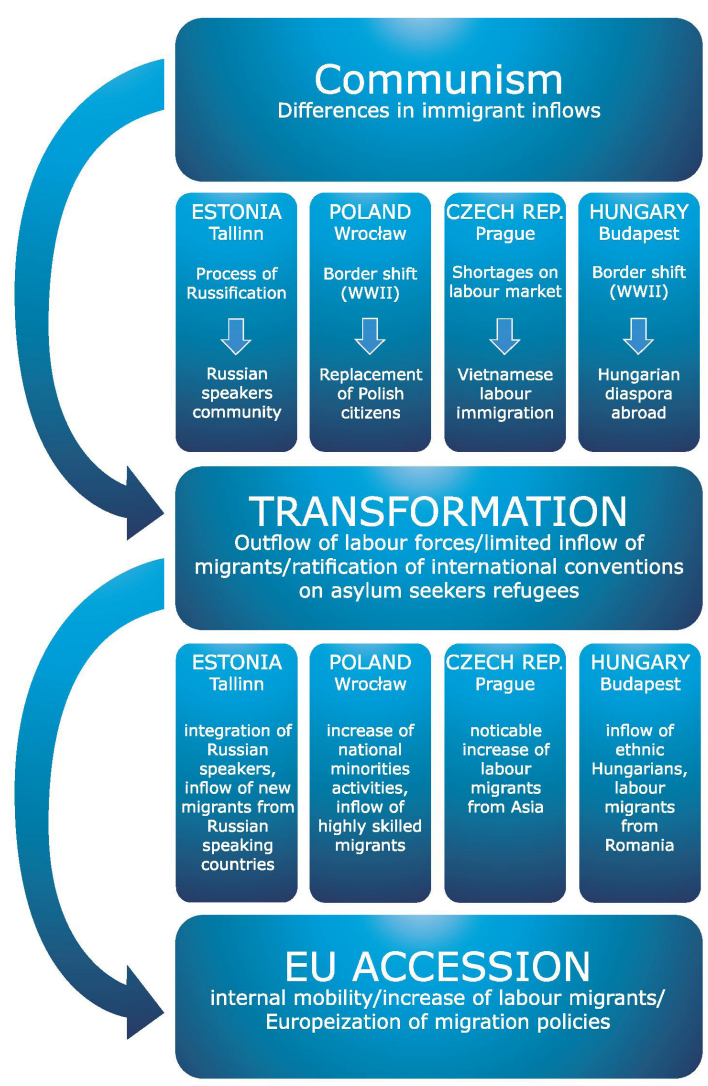

Fig 1. Source of differences in migration process in Prague, Budapest, Wrocław and Tallinn. Matusz Protasiewicz 2011

a milestone was set in 1995 with the introduction of a Parliamentary Commissioner for National and Ethnic Minorities Rights ('Minorities Ombudsman'). NGOs and community organisations play a marginal role in the implementation of policies.

The migration situation in Hungary from 2004 has been shaped by European integration, but there are no strong efforts to create a more pronounced integration policy. In fact, since the last elections in 2010 there has been talk of downgrading the existing constitutional protection of fundamental rights (Tóth 2009). Important elements that are still missing include a consistent integration policy and a central theme for intergroup policies. These policies are complex and the whole area is subject to other priorities that cannot be decided autonomously by the Municipalities. It is further complicated by the fact that this field is entangled with politics concerning ethnic Hungarians in neighbouring countries.

\section{Czech Republic}

In addition to the approximately 400,000 foreigners legally residing in the country in 2009 , there were an estimated $100,000-$ 200,000 undocumented foreigners. Integration is understood mainly as integration into the labour market and this narrow understanding leads to a one-sided perception of immigration and its impacts, as the 'value' of migrants by Czech society is defined by their economic utility. Intergroup policies do not rank high on the political agenda but there is already a rising consciousness about their importance among political decision-makers. 
Poland

Poland was very multicultural before WWII, but the communist regime attempted to create a homogeneous society. Poland is a net emigration country and immigration is relatively constant and consists mostly of circular migrants from neighbouring countries (mainly the Ukraine) responding to labour market needs. Records from the population register show that in 2006, the number of foreign permanent residents was $54,800(0.14 \%$ of the population) and they came mainly from the Ukraine, Germany, Belarus, the Russian Federation, Vietnam, Armenia, US, France and the UK (Kępińska 2007; Matusz Protasiewicz 2009b).

According to the Act on National and Ethnic Minorities and Regional Language (Ustawa o Miniejszościach Narodowych i Etnicznych oraz Języku Regionalnym), there are 9 national and 4 ethnic minorities. The development of migration policy in Poland is still at an early stage and there is no general strategy or clearly formulated integration policy - integration programs are ad hoc formulated actions, in many cases organized by NGOs. In 2006-2009 the law was changed to liberalise access to the labour market and in 2011, an inter-ministerial working group presented a document titled 'Polish Migration Strategy' which recommended the introduction of system-related changes to migration policy. However as Poland has not been confronted with the need to deal with bigger waves of migrants, the strategy of intergroup policies has remained a declaration repeated by consecutive governments.

Estonia

During the communist regime, the former republics of the USSR were influenced by Russification, a process that has caused a particularly politically sensitive situation. Estonia's immigrants are very limited in number but the number of Russian speakers reached about $26 \%$ of the total population (in Tallinn $46 \%$ ) (Statistical Office of Estonia 2007). In addition, due to their historical links many citizens of the Scandinavian countries have also settled in Estonia.

The situation in Estonia after transformation was sensitive and the question of citizenship was broadly discussed during the 1990s. More recently Estonia was obliged by the EU to regulate the rights of Russian speakers and the introduction of EC Directive 2003/109/EC means that non-Estonian citizens are free to live there as "long -term residents".

The Law on the Cultural Autonomy of National Minorities defines minorities, which allows them to constitute themselves as autonomous cultural or religious communities similar to the Jewish communities from the beginning of the 1990s The main goals for future integration policy were formulated in the 2008-2013 State Integration Programme which was prepared by academics and practitioners as a result of the commission of the Estonian Ministry of Finance.

Integration policy initiated in the late 1990s was addressed mainly to Estonia's Russian-speakers and. the knowledge and use of the Estonian language among non-Estonians remains a sensitive issue.
Intercultural policy-making in the cities: actions and policy network

Budapest

According to data from the 2001 census, the largest nonHungarian ethnic groups were Roma $(12,266)$ and Germans $(7,014)$ although there were also sizeable Chinese, Greek, Slovak and Ukrainian communities (Hungarian Statistical Office 2003). Budapest's political and administrative bodies are at the initial stages of development of intergroup policies and the responsibility for dealing with the integration issue lies at a national level. According to the Municipality, the city's official policy is that Budapest is a multicultural city but this is not expressed explicitly in law or in special political or legislative tools.

Established in 1995 as an independent organisation, Menedék (Migránsokat Segítő Egyesület or Hungarian Association for Migrants) represents 78 ethnic associations (2008), over half of which are ethnic Hungarian. It plays a crucial role as it represents the interests of migrants to political bodies and participates in the creation of migration policy.

In 2006, Hálózat, a national network of 22 member organizations dealing with migrants was founded. Its goal was to establish cooperation between organizations and experts and to strengthen representation of members' interests.

At time of our fieldwork, the estimated number of Chinese living in Budapest ranged between 25,000 and 60,000 people. Both the Chinese and Vietnamese organisations' networks are focused on cultural, economic and religious affairs but these communities are not really integrated into the urban society. They have, however, established networks that make them economically successful (Irimiás 2008). While ethnic Hungarian immigrants or the German minority are well integrated, Africans and Roma are 'at the bottom'.

Most ethnic associations are not very active and have only a few members who organise one or two cultural events every year. In February 2010, Hungary's Minority Ombudsman proposed that a House of Minorities in Budapest be set up to halt the assimilation of national and ethnic minorities and protect their cultural assets.

\section{Prague}

In 2007 Prague numbered 1,258,062 inhabitants of whom $10.2 \%$ were foreign nationals. The 2001 Population Census reported that $93.4 \%$ of the population of Prague claimed Czech origin while the second most important nationality was Slovak.

Prague considers communication with national minorities to be very important, but it has to act within the framework of national regulations. For example in 1997, an Advisory Board for National Minorities was created, aspects of cooperation with ethnic groups and their organizations are guaranteed by the 'Act on the Rights of Members of National Minorities', while the Act on the Capital City of Prague (2000) refers to the establishment of a Committee for National Minorities within the City Council.

One of the first visible manifestations of a policy on intergroup relations was the foundation of the Multicultural Center Prague (Multikurní Centrum Praha) in 1999 and a second milestone was 
set in 2007 when the city opened the House of National Minorities. This was an important step towards building awareness of diversity issues among the urban population as up to that point, the city had not maintained formal contacts with all ethnic organisations and it was hoped that the House of National Minorities would provide such a platform.

Cooperation between the Municipality and NGOs is also appreciated by both sides, and it gave rise to important outcomes such the creation of a website for foreigners (www.cizinci.cz; where cizinci is the Czech word for "foreigners"). Other important NGOs include 'SLOVO 21' which was founded to help immigrants integrate, the 'Forum of Ukrainians of the Czech Republic' and 'Klub Hanoi'. The latter is a good model that could be followed by other small Asian groups, such as the North Koreans and Mongolians.

\section{Wrocław}

After the border change between Germany and Poland after WWII, the German city of Breslau became the Polish city of Wrocław and over the following years, the whole population of the city changed.

Wrocław provides an interesting example of an attempt to promote a national minority policy in order to create a more multicultural atmosphere, although it is important to distinguish between national minorities and newly arrived migrants. More recently, the Law on National Minorities and access to different European Union grants have activated a number of minority organisations who want to preserve their cultural heritage. According to official statistics, by the end of 2008 there were 3,980 foreigners living in the Wrocław agglomeration (less than $1 \%$ of the population), consisting of students from countries to the east of Poland (Ukraine, Belarus, Russia, Kazakhstan), students from the Western, workers of multinational corporations (from South Korean, Germany, Sweden and France) as well as Muslims (Matusz Protasiewicz 2009b).

From early 1990s, Wrocław has based its strategy on two pillars: as an investor-friendly and multicultural city. So although the policy towards different minority groups is not explicitly formulated, it can be considered part of the development policy of the city. In 2008, the Group for National and Ethnic Minorities and International Cooperation was established with the goal of supporting activities that promote the cultural tradition of minorities.

Minority organisations in Wrocław tend to be based on either culture or religion. Examples of the former include the Ukrainian minority organisation which has a long tradition in cultural activities, as well as the German Social and Cultural Society (Deutsche Sozial- und Kulturelle Gesellschaft in Breslau).

Among religious minority organisations, the most important are the Jewish and the Muslim communities. The latter is focused on the Muslim Cultural Centre, which is the only Muslim organisation in the city.

In summary, the development of intergroup policy in Wrocław is at an early stage and actions are taken on an ad hoc basis as part of the promotion of the multicultural image of the city.
Tallin

In order to understand the local policy-making process in Tallinn, it is important to note that $54.9 \%$ of Tallinn's population are Estonian and $36.5 \%$ are Russian. The biggest minority group are Russian speakers but this group has a diverse structure.

Overall there are over 200 registered minority societies belonging to 17 umbrella organisations that include The International Association of National and Cultural Societies Lüüra, and Russkij Dom, a cultural organisation of Russian-speakers.

Tallinn's financial support of minority organisations contributes to cooperation between them. For example, the city financed the renovation of the Russian House and sponsored its activities, making it the only Russian culture centre outside Russia entirely sponsored by local authorities.

According to the Estonian Open Society Institute research carried out in 2007, three-quarters of the residents of Tallinn thought that the integration process was unsuccessful. This result stimulated the city authorities to develop integration activities and as a result, local policy is based on the state integration program and is addressed to all minorities. The Kodurahu (Peace in the Community) program involves a working group of 15 leaders of minority organizations and aims to improve relations between Estonians and non-Estonians by focusing on the development of inter-group relations.

\section{An appraisal of similarities and differences}

\section{between the four cities}

Although our analysis focused on the municipal level, in Central and Eastern Europe the national context can't certainly be ignored. In the Czech Republic, discussion of immigration and integration issues is highly emotional and public opinion is generally negative. In Hungary, anti-immigrant sentiments have been rising recently which is related to political developments. In Poland the debate is more about emigration and its consequences while in Estonia, the focus of public discussion is still on Estonian-Russian relations. Local policymaking in all four cities is characterised by negotiation and pragmatism, which are common characteristics of intergroup policies.

In all four cities, NGOs and migrant or religious associations are new phenomena. Most were founded in the 1990s and they work in partnership with public authorities which means that although they are official actors, they are less involved in intergroup policy-making.

There is not only little systematic cooperation between immigrant and minority organizations but policy measures also emphasise the latter. However the problems of minorities and immigrants are completely different which makes it difficult to introduce policies for both groups.

In Budapest, existing strategies of intercultural policies could be described as 'embryonic' as immigration policy has been developed as a response to the requirements of EU accession. In contrast to Budapest, Prague has invested more money in projects that tackle intergroup affairs while in Tallinn, there is still a visible division between Estonian and non-Estonian organisations. 
In both Prague and Budapest, the low participation of migrants in NGOs is evident and is undoubtedly a disadvantage in establishing intercultural relations. Across Central and Eastern Europe as a whole, the remnants of a bureaucratized system of interaction with territorial authorities is a barrier which stands in the way of more active participation by migrants.

NGOs have also been undermined by unstable funding which leads to an uncertain future. During the course of our fieldwork, NGO representatives complained about their struggle with authorities against the restrictions towards migrants.

Tallinn is a special case as intergroup relations have gone through different phases after transformation compared with the other cities considered during the research. In Tallinn, the initial phase focused mainly on citizenship, legal regulations in this field as well as developing identity and loyalty towards Estonia as an independent state. In the 'Kodurahu' program, the city of Tallinn initiated its own activities in the field of diversity and intergroup dialogue.

Wrocław is behind Prague and Tallinn although it is politically more open than Budapest. The limited number of migrants and their status has not forced the Municipality to develop any policy in this field. As a result, intergroup relations are reduced only to a national minority and the Muslim Cultural Centre which are given ad hoc given grants, although this should be perceived as positive cooperation. The City expressed its interest in intercultural issues as a visible sign of a multicultural image, a strategy that has been strengthened by EU accession and participation in different competitions (EXPO, Euro 2012, Capital of Culture), although there was no clear plan to include national minorities or migrants in this policy.

Why is cooperation between the city and immigrant associations so difficult? The main reason is that municipalities lack instruments for solving the real issues facing intergroup relations and this means that urban policies can only focus on 'soft' measures.

Crucially, with the exception of the Czech Republic, neither NGOs nor immigrant associations in the CEE countries considered appear to be involved in the intergroup policy arenas, and scientific experts are of minor importance. The increasing incorporation of NGOs into local policymaking can be observed in all four cities considered in this study In Tallinn, the role of experts is more visible on the national than on the local level, although it is sometimes difficult to distinguish between the two.

\section{Conclusion}

It is obvious that in Central and Eastern Europe, intergroup policies are far from being as developed as in Western Europe. On the national as well as municipal levels, the migration issue is not politicised and intergroup policies do not rank high on the agendas of political decision-makers. The major reasons for this are a lack of public awareness and the small size of migrant communities.

In general, it can be said that bureaucratic attitudes still prevail. Decision-making processes are top-down, institutional structures are centralised and the role of the Ministry of the Interior is key. The distribution of power is of central relevance and the dominant authority is definitely at the national level.

There is local divergence in the framework conditions of the politicisation In terms of intergroup policies, Prague is the most advanced while in Poland there is a discrepancy between the official declarations of Wrocław a multicultural city and the lack of actual policies to support this. The situation in Tallinn is quite different because of the co-existence of two established "paralIel" societies while in Budapest, the political situation is a fertile breeding ground for intercultural problems. Time will tell if the conditions for the systematisation of this policy arena will change. In all four cities intergroup policies are not linked with other policy arenas. The basic institutions for policies have been created, but more time is necessary to establish communication structures with the immigrant associations. There are four main actors in the arena of local intergroup policy making, namely elected political actors, public officials, civil society organisations and scientific experts. Given the rather small sizes of the immigrant communities and the dominant economic view on immigration it may be said that the development of adequate institutionalized policies on intergroup relations in the four cities will require more time.

\section{References}

Alexander, M 2007, Cities and labour immigration. Comparing policy responses in Amsterdam, Paris, Rome and Tel Aviv, Ashgate, Aldershot

Brouček, S 2003, Aktuálni problém adaptace vietnamského etnika $w$ ČR, Etnologicy ustav AV ČR, Praha

Caponio, T 2010, 'Conclusion. Making Sense of Local Migration Policy Arenas', in Caponio, T, Borkert, M, (eds.), The Local Dimension of Migration Policymaking, IMISCOE Report Series, Amsterdam University Press, Amsterdam

Desponds, A, Lesińska M 2008, 'Obecność i funkcjonowanie społeczności imigranckich w Polsce. Przypadek Ukraińców i Wietnamczyków we Wrocławiu', in: Grzymała-Kazłowska, A, Między jednością a wielością. Integracja odmiennych grup i kategorii imigrantów w Polsce, OBM, Warsaw
Drbohlav, D 2009, Czechia as a New Immigration Country? IDEA Working Papers, Prague

Hárs, Á, et al 2009 Immigration countries in Central and Eastern Europe. The Case of Hungary, Idea Working Papers, Budapest

Dutkiewicz, R 2006, The Strategy "Wroclaw in the Perspective 2020 plus". Avaliable from <http://bip.um.wroc.pl/wps/wcm/connect/5f 3b6680453b27dab9caf9ffcdc6cfec/strategia_Wroclaw2020plus_ en.pdf?MOD=AJPERES>. [30 April 2012].

Irimiás, A 2008, 'A Budapesten élő kínai közösség' ('The Chinese community living in Budapest'), Földrajzi Értesitő. LVII, pp. 469-481

Kępińska, E 2007, 'Recent Trends in International Migration. The 2007 SOPEMI Report for Poland;, CMR Working Papers, No. 29/(87), Warsaw 
MISCELLANEA GEOGRAPHICA - REGIONAL STUDIES ON DEVELOPMENT

Vol. 16 • No. 2 - 2012 • pp. 5-10 • ISSN: 2084-6118 • DOI: 10.2478/v10288-012-0026-1

Matusz Protasiewicz, P 2009a, Intergroup relations and intercultural policies, case of Tallinn (Estonia), Eurofound. Avaliable from <http:// www.eurofound.europa.eu/areas/populationandsociety/clip.htm>. [30 June 2012].

Matusz Protasiewicz, P 2009b, Intergroup relations and intercultural policies, case of Wrocław (Poland), Eurofound. Avaliable from <http:// www.eurofound.europa.eu/areas/populationandsociety/clip.htm>. [30 June 2012].

Nyíri, P 2007, Chinese in Russia and Eastern Europe: A Middleman Minority in a Transnational Era, Routledge, London

Reinvelt, R 2000, Integration, Multinational Estonia and Estonian-Language Press. Soviet - Time Immigrants in Newspapers Edasi/Postimees in 1998-2000, Integration Foundation.

Tesser, M, L 2005, The impact of the post-cold war European Minority Rights regime on inter- ethnic relations in Estonia and Latvia. Avaliable from < http://aei. pitt.edu/3171/>. [20 April 2010].
Tóth, J 2009, Hungary, in: 'Annual Overview of International Migration in Central and Eastern Europe - 2009'. Avaliable from http://www.migrationonline.cz/centraleasterneurope/2009/\#n3>. [20 June 2010].

Czech Statistical Office 2009, Foreigners in the Czech Republic 2008. Avaliable from <http://www.czso.cz/csu/2008edicniplan.nsf/engkapitola/1414-08-2008-0900>. [20 August 2010].

European Union Council Directive 2003/109/EC. Avaliable from <http:// eur-lex.europa.eu/LexUriServ/LexUriServ.do?uri=OJ:L:2004:016:00 44:0053:en:pdf>. [25 August 2010].

Hálózat 2011. Avaliable from <http://www.halozat.info.hu/node>. [10 March 2012].

State Integration Program 2008-2013 Estonia. Avaliable from <http://www.kul.ee/webeditor/files/integratsioon/Loimumiskava _2008_2013_ENG.pdf>. [12 June 2010].

Statistical Office of Estonia <http://www.stat.ee/statistics>. [20August 2012]. Statistical Office of Hungary <http://www.ksh.hu/>. [10 September 2010]. 